\title{
High Density Lipoprotein Cholesterol (HDL-C) Status in Patient's of Acute ST-Elevation Myocardial Infarction (STEMI)
}

\author{
Mohammad Kafil Uddin ${ }^{*}$ \\ Farhena Ahmed ${ }^{2}$ \\ Md. Kamal Hossain ${ }^{2}$ \\ Monira Khatun ${ }^{3}$ \\ Mohammad Musa Meah ${ }^{4}$ \\ ${ }^{1}$ Department of Cardiology \\ Mirsarai Upazila Health Complex \\ Chittagong, Bangladesh. \\ ${ }^{2}$ Department of Biochemistry \\ Chattagram Maa-O-Shishu Hospital Medical College \\ Chittagong, Bangladesh. \\ ${ }^{3}$ Department of Physiology \\ Chattagram Maa-O-Shishu Hospital Medical College \\ Chittagong, Bangladesh. \\ ${ }^{4}$ Department of Pediatrics \\ Bangladesh Institute of Tropical and Infectious Diseases (BITID) \\ Chittagong, Bangladesh.
}

\section{*Correspondence to:}

\section{Dr. Mohammad Kafil Uddin}

Junior Consultant

Department of Cardiology

Mirsarai Upazila Health Complex

Chittagong, Bangladesh.

Mobile : +8801711136063

Email: Kafilcardio@gmail.com

\begin{abstract}
Background : Decrease plasma High Density Lipoprotein Cholesterol (HDL-C) and increase triglyceride are major dyslipidemia in our country due to effects of carbohydrate rich diet. The relationship of low level of HDL $-\mathrm{C}$ in patient's of AMI and its extents of severity in coronary artery disease will be very important for future management as well as prevention of Coronary Artery Disease (CAD). Objective : The aim of this study is to assess the level of serum HDL-C in AMI patient and to assess whether low serum HDL-C level is an independent risk factor for acute ST elevation MI. Methods : It is a hospital based cross sectional observational study. 280 patients of acute STEMI who are admitted in coronary care unit selected for study. After estimation of serum lipid profile of these patients their serum level of HDL-C were used to detect the relationship between serum HDL-C and acute ST elevation MI. Results : In our study, among the case group (280 patiens) lipid profile estimation showed that about $64 \%$ patients of acute STEMI have low level of serum HDL-C. The other lipid fractions like triglyceride, low density lipoprotein cholesterol as well as total cholesterol were high in about $24 \%, 39 \%$ \& $44 \%$ but normal in $76 \%, 61 \%$ \& $56 \%$ respectively. Conclusion : There is an independent inverse association of serum HDL-C in patients of acute STEMI and its an important indepedent risk factor.
\end{abstract}

Key words : HDL-C; STEMI; CAD.

\section{INTRODUCTION}

Coronary heart disease is the most common cardiovascular disease and the major cause of death in middle age and older people. Dyslipidemia is known as major cardiovascular risk factor and is responsible for most coronary artery disease. One of the major predisposing factors to atherosclerosis is an abnormal lipoprotein metabolism and it may be present in over $70 \%$ of patient with premature $\mathrm{CAD}^{1}$. High concentration of LDL cholesterol and low level of HDL cholesterol are able to promote atheroma formation and are recognized as particularly important risk factor for atherosclerosis and $\mathrm{CAD}^{2}$.

About $40 \%$ of coronary heart disease patients do not have elevated levels of LDLcholesterol and many of them have low levels of HDL cholesterol as their primary lipid abnormality. Overall, about $25 \%$ of patients with coronary heart disease have low level HDL cholesterol in the absence of elevated LDL-cholesterol ${ }^{3}$.

About $58 \%$ of patients with myocardial infraction were found to have hyper cholesterolemia in contrast only with $10 \%$ among normal individual ${ }^{4}$. Incidence of IHD is increasing in developing countries including Bangladesh with the improvement of socioeconomic status, urbanization and changes of dietary habits and lifestyle ${ }^{5}$. 
Low HDL is present in $35 \%$ of men and $15 \%$ of women. In one study, low HDL occurred in approximately $63 \%$ of patients with CAD. Reducing cholesterol level in the healthy middle aged men without CHD reduce their risk in proportion to the reduction in LDL cholesterol and the increasing in HDL cholesterol as a result rates of myocardial infarction will be reduce significantly ${ }^{6,7}$.

Transport of cholesterol from peripheral tissues to the liver, for subsequent catabolism and excretion is a function of plasma High Density Lipoprotein Cholesterol (HDL-C). Reduction of plasma HDL-C accelerates the development of atherosclerosis. Recent studies indicate that the antioxidants and antiinflammatory properties of HDL-C also inhibits atherogenesis ${ }^{8}$.

Low level of HDL-C made a three fold greater contribution to the presence of future Coronary Heart Disease (CHD) than other lipoprotein ${ }^{9} .2$ to 3 percent decrease in CHD risk for each $1 \mathrm{mg} / \mathrm{dl}$ increase in HDL-C level, after adjustment to control for other risk factor ${ }^{10}$. HDL-C inversely related to the risk of Myocardial Infarction might be explained by the potential major protective role of $\mathrm{HDL}-\mathrm{C}$ in state of acute inflammation and its antithrombotic properties ${ }^{11}$.

Severity of the CAD is inversely related with level of HDL- C in both man and women. It is estimated that for each $1 \mathrm{mg} / \mathrm{dl}$ increase in HDL-C, risk for a CAD event is reduced by $2 \%$ in men and $3 \%$ in women ${ }^{12}$.

This study was carried out to observe the status of serum HDL-C level in acute ST elevation MI and the impact of plasma low $\mathrm{HDL}-\mathrm{C}$ on extend and severity of CAD in patients of AMI.

\section{MATERIALS AND METHODS}

The present study was a hospital based, prospective observational study. The study was conducted in the Department of Coronary Care Unit, Chittagong Medical College Hospital, Chittagong, between $1^{\text {st }}$ November 2008 to $30^{\text {th }}$ November 2009.

The study population consisted of diagnosed case of Acute MI admitted in the Department of Cardiology, Chittagong Medical College Hospital, Chittagong during study period were selected as cases by the process of purposive sampling.

\section{RESULTS}

Table 1 : Distribution of the study subjects by clinical diagnoses $(n=280)$.

$\begin{array}{lcc}\text { Clinical Diagnosis } & \text { Frequency } & \text { Percentage (\%) } \\ \text { AMI (Inferior) } & 101 & 36.1 \\ \text { AMI (Antero-septal) } & 55 & 19.6 \\ \text { AMI (Extensive Anterior) } & 54 & 19.3 \\ \text { AMI (Anterior) } & 52 & 18.6 \\ \text { AMI (Infero-lateral) } & 5 & 1.8 \\ \text { Others } & 13 & 4.7 \\ \text { Total } & \mathbf{2 8 0} & \mathbf{1 0 0 . 0}\end{array}$

Table 1 shows that AMI (Inferior) was detected among maximum patients about 36\%), while AMI (Antero-septal) was the second (About 20\%). Among the study subjects significant numbevr of patient developed extensive anterior MI which was about $19.3 \%$.

Table 2 : Distribution of the study subjects by biochemical levels $(\mathrm{n}=280)$.

\begin{tabular}{lrrrr} 
Biochemical Variables & \multicolumn{1}{c}{ Mean } & \multicolumn{1}{c}{ \pm SD } & Median & Range \\
Total Cholesterol (mg/dl) & 195.50 & 42.73 & 192.00 & $115-330$ \\
Triglyceride $(\mathrm{mg} / \mathrm{dl})$ & 165.22 & 103.22 & 140.00 & $60-743$ \\
LDL- Cholesterol (mg/dl) & 122.71 & 38.03 & 120.00 & $51-248$ \\
HDL- Cholesterol (mg/dl) & 39.59 & 8.68 & 38.00 & $22-65$ \\
\hline
\end{tabular}

Table 2 showed that the biochemical values among the study subject where mean total cholesterol was $195.5 \pm 42.73$ and the range was 115 to $330 \mathrm{mg} / \mathrm{dl}$. The mean triglyceride level was $165.2 \pm 103.2$, where the highest value was $743 \mathrm{mg} / \mathrm{dl}$.The mean HDL-C was $39.59 \pm 8.68 \mathrm{mg} / \mathrm{dl}$.

Table 3 : Distribution of the study subject by biochemical levels $(\mathrm{n}=280)$

\begin{tabular}{llcc} 
Biochemical Levels & & Frequency & Percentage (\%) \\
Total Cholesterol Level & Normal & 157 & 56.1 \\
& Elevated $(>200 \mathrm{mg} / \mathrm{dl})$ & 123 & 43.9 \\
Triglyceride Level & Normal & 213 & 76.1 \\
& Elevated $(>200 \mathrm{mg} / \mathrm{dl})$ & 67 & 23.9 \\
LDL-C Level & Normal & 172 & 61.4 \\
& Elevated $(>130 \mathrm{mg} / \mathrm{dl})$ & 108 & 38.6 \\
HDL-C Level & Normal & 102 & 36.4 \\
& Low $(<40 \mathrm{mg} / \mathrm{dl})$ & 178 & 63.6 \\
\hline
\end{tabular}

Table 3 shows biochemical profile of the study population revealed that $44 \%$ subjects had total cholesterol $>200 \mathrm{mg} / \mathrm{dl}$, about $24 \%$ of subjects had higher TG level. The level of serum LDL-C which was elevated in $38.6 \%$ subjects . The most important parameter and centre of total study is serum HDL-C level which was low in $63.6 \%$ of subject.

Table 4 : Distribution of biochemical variables by clinical diagnoses $(\mathrm{n}=280)$.

\begin{tabular}{|c|c|c|c|c|}
\hline \multirow[t]{2}{*}{ Clinical Diagnosis } & \multicolumn{2}{|c|}{ LDL-Cholesterol } & \multicolumn{2}{|c|}{ HDL-Cholesterol } \\
\hline & Normal & Elevated & Normal & Low \\
\hline AMI (Inferior) & $63(62.4 \%)$ & $38(37.6 \%)$ & $26(25.7 \%)$ & $75(74.3 \%$ \\
\hline AMI (Antero-septal) & $39(70.9 \%)$ & $16(29.1 \%)$ & $25(45.5 \%)$ & $30(54.5 \%$ \\
\hline AMI (Extensive Anterior & r) $30(55.6 \%)$ & $24(44.4 \%)$ & $19(35.2 \%)$ & $35(64.8 \%$ \\
\hline AMI (Anterior) & $29(55.8 \%)$ & $23(44.2 \%)$ & $23(44.2 \%)$ & $29(55.8 \%$ \\
\hline AMI (Infero-lateral) & $05(100.0 \%)$ & $00(0.0 \%)$ & $02(40.0 \%)$ & $03(60.0 \%$ \\
\hline AMI (Antero-inferior) & $00(0.0 \%)$ & $04(100.0 \%)$ & $04(100.0 \%)$ & $00(0.0 \%$ \\
\hline AMI (High Lateral) & $03(100.0 \%)$ & $00(0.0 \%)$ & $00(0.0 \%)$ & $03(100.0 \%$ \\
\hline $\begin{array}{l}\text { AMI (Anterior with } \\
\text { Posterior Extension) }\end{array}$ & $03(100.0 \%)$ & $00(0.0 \%)$ & $03(100.0 \%)$ & $00(0.0 \%)$ \\
\hline AMI & & & & \\
\hline Posterior Extension) & $00(0.0 \%)$ & $03(100.0 \%)$ & $00(0.0 \%)$ & $03(100.0 \%)$ \\
\hline & $\begin{array}{r}\chi^{2}=21.669 . \\
\text { Highl }\end{array}$ & $\begin{array}{l}\quad \mathrm{p}<0.01 \text {. } \\
\text { significant }\end{array}$ & $\begin{array}{r}\chi^{2}=23.999 . \\
\text { Highly }\end{array}$ & $\underset{\text { significant }}{p<0.01 .}$ \\
\hline
\end{tabular}

Volume 16, Issue 1, January 2017 
Table 4 shows the distribution of clinical diagnosis by biochemical levels. In inferior AMI patient $75 \%$ of subjects had low level of serum HDL-C and level of serum LDLcholesterol was elevated which were $34.7 \% 37.6 \%$.In other types of AMI serum HDL-C level were lowered and LDLcholesterol was elevated.Chi square test were done to evaluated the association which was highly significant $(\mathrm{p}<0.01)$

Table 5 : Distribution of HDL-C/LDL-C ratio by HDL-C and LDL-C levels $(\mathrm{n}=280)$ with independent $\mathrm{t}$ - test significances.

\begin{tabular}{llllc} 
HDL-C Level & Mean & \pm SD & Median & Range \\
Normal & 0.42 & 0.15 & 0.40 & $0.17-0.83$ \\
Low & 0.31 & 0.08 & 0.30 & $0.18-0.57$ \\
\hline
\end{tabular}

$\mathrm{t}=7.380 . \mathrm{df}=278 . \mathrm{p}=0.000$. Very highly significant. $\mathrm{p}<0.001$.

\begin{tabular}{llllc} 
LDL-C Level & Mean & \pm SD & Median & Range \\
Normal & 0.40 & 0.12 & 0.38 & $0.23-0.83$ \\
Elevated & 0.26 & 0.06 & 0.24 & $0.17-0.45$ \\
\hline
\end{tabular}

$\mathrm{t}=11.131 . \mathrm{df}=278 . \mathrm{p}=0.000$. Very highly significant. $\mathrm{p}<0.001$.

Table 5 shows the evident that the ratio of HDL-C/LDL-C. When HDL-C level is normal the mean ratio is $0.42 \pm 0.15 \mathrm{SD}$ in comparison to low HDL-C where mean ratio $0.31 \pm 0.08 \mathrm{SD}$. The $\mathrm{t}$ test of significance was done which is very highly significant $\mathrm{p}<0.001$. On the contrary when LDL-C level is normal the mean ratio was $0.40 \pm 0.12 \mathrm{SD}$ in comparison to elevated LDL-C where mean ratio was $0.26 \pm 0.06$ SD. Here $t$ test of significance was done which is very highly significant $\mathrm{p}<0.001$.

\section{DISCUSSION}

Multivariate analysis shown that HDL-C was a strong and independent predictor of acute ST elevation of MI. Considering lipid profile, mean serum HDL-C level was $39.59 \pm 8.68$ SD $(p<0.01)$ and was statistically significant. Only $36.4 \%$ of subjects have had their normal level of serum HDL-C $.63 .6 \%$ patient had their serum HDL-C below $40 \mathrm{mg} / \mathrm{dl}$. These data support that low serum HDL-C is an important and independent risk factor for acute ST elevation MI .Our observations were also similar with Gordon et al (1989) Rahman et al (2001) where they found STEMI was most common clinical diagnosis in low HDL-C patients ${ }^{5}$. Besides that serum HDL-C level were low $74.3 \%$ in inferior MI cases and also low in $64.8 \%, 60 \%$, $55.8 \%, 54.5 \%$, cases of extensive anterior ,inferolateral, anterior, anteroseptal MI respectively. Correlated with cases of similar clinical diagnosis having normal serum HDL-C, $\chi^{2}$ test was done $\left(\chi^{2}=23.99, \mathrm{p}<0.01\right)$ which was highly significant. Similar result of serum HDL-C was found by Ballantyne et al $(1999)^{12}$.

\section{CONCLUSION}

We found that most of the patients with acute STEMI have low serum HDL-C. Most patients with acute STEMI do not have substantially elevated total or LDL-C. Instead, low serum HDL$\mathrm{C}$ is frequently the predominant abnormality. It means there is an independent inverse association of serum HDL-C in patients of acute STEMI and it is an important independent risk factor. So, it should be controlled properly.

\section{DISCLOSURE}

All the authors declared no competing interests 


\section{REFERENCES}

1. Yusuf S \& Ounpuu S. Trackling the growing epidemic of cardiovascular disease in south Asia. Am J cardiol. 2001;38:688-689.

2. Tarchalski J, Marwick TR \& friedman SB. A new method of scoring coronary angiogram to reflect extent of coronary atherosclerosis and improve correlation with major risk factors. Am Heart J. 1990;119:1262.

3. Despre's JP, Lemieux I \& Dagenais GR. HDL-C as a marker of coronary heart disease risk : The Quebec Cardiovascular study. Atherosclerosis. 2000;153:263-272.

4. Willam T Foley. Advances in the management of cardiovascular disease. Circulation. 1980;1:159.

5. Rahman MA, Ali MA, Majumdar AAS, Haque KMHSS, Banoo H \& Zaman MA. Dyslipidaemia and coronary artery disease. Bangladesh Heart Journal. 2001;18(1):30-35.

6. M.Dominique Ashen, Roger S \& Blumenthal MD, Low HDL Cholesterol levels.NEJM.2005;353:1252-1260.

7. Whitney Ej et al. A randomizes trial of a strategy for increasing high density lipoprotein cholesterol levels: Effects of progression of coronary heart disease and clinical events. Am J Intern Med.142(2):95-104.

8. Expert panel on Detection, Evaluation and Treatment of High Blood Cholesterol in Adults.Executive summary of the third report of the National Cholestrol Education Program (NCEP) (Adult treatment panel III). JAMA.2001;285:2508-2597.

9. Miller NE, Forde OH, Thelle DS \& Mjos OD.The Tromso Heart Study:HDL and coronary heart disease:A prospective case-control study. Lancet. 1977;7:965-970.

10. Assmann, G.Gchulte,H, Relation of High density lipoprotein cholesterol and triglycerides to incidence of atherosclerotic coronary artery disease (The PROCAM experience).Prospective cardiovascular Munsterudy, Am J Cardiol. 1998;70:733-737.

11. Boden WE. High-density lipoprotein cholesterol as an independent risk factor in cardiovascular disease: Assessing the data from Framingham to the veterans Affairs High-density Lipoprotein intervention Trial. Am J Cardiol.2000;86(suppl):19L-22L.

12. Ballantyne CM, Herd JA \& Ferlic LL. Influence of low HDL-C on progression of coronary artery disease and response to Fluvastatine therapy.Circulation.1999;99:85-88. 